\title{
Has Global Health Law Risen to Meet the COVID-19 Challenge? Revisiting the International Health Regulations to Prepare for Future Threats
}

\section{Global Health Law}

\author{
Lawrence O. Gostin, \\ Roojin Habibi, and \\ Benjamin Mason Meier
}

Global health law is essential in responding to the infectious disease threats of a globalizing world, where no single country, or border, can wall off disease. Yet, the Coronavirus Disease(COVID-19) pandemic has tested the essential legal foundations of the global health system. Within weeks, the SARS-CoV-2 coronavirus has circumnavigated the globe, bringing the world to a halt and exposing the fragility of the international legal order. Reflecting on how global health law will emerge in the aftermath of the COVID-19 pandemic, it will be crucial to examine the lessons learned in the COVID-19 response and the reforms required to rebuild global health institutions while maintaining core values of human rights, rule of law, and global solidarity in the face of unprecedented threats.

Unlike anything seen since the Great Influenza Pandemic of 1918, health systems have faltered under the strain of the COVID-19 pandemic, with cascading disruptions throughout the world. Borders have closed, businesses shuttered, and daily life brought to a standstill. In the absence of a treatment or vaccine, governments worldwide have sought to ensure physical distancing across their populations; yet, vulnerable, marginalized, and disadvantaged populations have faced structural obstacles in meeting these necessary imperatives to contain the disease. This unequal risk of infection is exacerbating health inequities - within and across nations - with weak health systems lacking the capacity to implement mitigation strategies, test at-risk populations, or treat infected individuals. As the coronavirus sweeps across unprepared nations, national legal responses have proven unable to prevent, detect, or respond to the pandemic, and the sheer scale of human, social, and economic upheaval has challenged global health law as never before.

Framing global health law to control infectious disease, the International Health Regulations (IHR) have established a global surveillance and reporting system and set national minimum mandatory controls to prevent disease and maximum permissible limitations on individual rights, state sovereignty, and commercial interests. Last revised in 2005 following the shortcomings in national and global responses to the severe acute respiratory syndrome (SARS) epidemic, the revised IHR provide a legal framework through the World Health Organization (WHO) to build national capacity for infectious disease prevention and detection and to strengthen global governance to address any public health emergency of international concern. While these IHR obligations were intended to facilitate international coordination in the context of public health emergencies, nationalist responses have challenged global governance in addressing this pandemic challenge. Amidst challenging global health circumstances, WHO has faced increasing IHR violations from states and, as a consequence, limited influence in the COVID-19 response.

Lawrence O. Gostin, J.D., LL.D. (Hon.), is University Professor at Georgetown University and the Founding Linda D. E' Timothy J. O'Neill Professor of Global Health Law at Georgetown University Law Center and Director of the World Health Organization Center on National and Global Health Law. Roojin Habibi , J.D., M.Sc., is a Research Fellow at the Global Strategy Lab and a Doctoral Candidate at Osgoode Hall Law School, York University. Benjamin Mason Meier, J.D., LL.M., Ph.D., is an Associate Professor of Global Health Policy at the University of North Carolina at Chapel Hill and a Scholar at the O'Neill Institute for National and Global Health Law. 
Global health law remains crucial to preventing, detecting, and responding to COVID-19 - implementing the IHR to control the rapid spread of this novel coronavirus and this column explores the long evolution and continuing limitations of this WHO framework. Outlining the international legal landscape, this column examines the evolution of global governance over infectious disease, describing how limitations of global health governance led to the aim to structure a harmonized surveillance, reporting, and response system across WHO member states - with these regulations automatically binding on all WHO member states unless explicitly rejected. Yet, the applicability of the IHR was limited to only three select diseases (cholera, plague, and yellow fever), and as the world faced a continuous stream of emerging and re-emerging diseases, the principal international legal instrument for preventing,

\section{Reflecting on how global health law will emerge in the aftermath of the COVID-19 pandemic, it will be crucial to examine the lessons learned in the COVID-19 response and the reforms required to rebuild global health institutions while maintaining core values of human rights, rule of law, and global solidarity in the face of unprecedented threats.}

contemporary revision of the IHR. This column then analyzes the implementation of the revised IHR in the COVID-19 response, reflecting both the promise of the IHR in promoting global solidarity and the weaknesses of the IHR in realizing an effective international response to this global threat. Given the continuing limitations of the IHR, this column considers reformed international legal authorities and new international legal instruments to bind states together under global health law in facing future pandemic threats.

\section{The Legal Landscape}

Drawing from the long history of international health law described in the opening column on "Global Health Law,"1 the 1946 WHO Constitution provided WHO with the authority to negotiate conventions, regulations, and recommendations on any public health matter. With this broad constitutional authority to regulate public health, WHO assumed governance over the IHR as an international legal framework to control infectious disease. The IHR detecting, and responding to infectious disease outbreaks was increasingly seen as inadequate.

Despite calls for the revision of the IHR, it took an outbreak of a novel coronavirus to prompt international action. SARS emerged in Guangdong, China in late 2002, but China did not inform WHO of this emerging threat - as SARS was not one of the three diseases covered by the IHR. China's delay in accurately reporting the SARS outbreak - compounded by the use of domestic legal restrictions inconsistent with public health practice - drew widespread international condemnation, raising calls for WHO action. ${ }^{2}$ With SARS highlighting the weaknesses of international law to control for infectious disease, the international community committed with remarkable speed to updating the breadth, scope, and notification obligations under the IHR.

The 2005 revision of the IHR provides the contemporary legal framework to prevent, detect, and respond to public health emergencies of international concern. The IHR were revised to achieve a higher level of global health security while avoiding unnecessary interference to international traffic and safeguarding human rights in the public health response. ${ }^{3}$

Looking beyond specific infectious diseases, IHR (2005) codified the versatile and encompassing category of a Public Health Emergency of International Concern (PHEIC), which includes any extraordinary event that:

1. constitutes a public health risk to other states through the international spread of disease (broadly defined as "any illness or medical condition, irrespective of origin or source, that presents or could present significant harm to humans") and

2. potentially requires a coordinated international response. ${ }^{4}$

Through National IHR Focal Points, states bear an obligation to notify WHO within 24 hours of all detected events within their territory which may constitute a PHEIC. ${ }^{5}$ Based upon information received from both state and non-state sources (e.g., media and online sources, civil society, and other states), the WHO DirectorGeneral has the ultimate authority to determine whether an event constitutes a PHEIC, considering:

1. information provided by the State Party within whose territory an event is occurring;

2. advice from an ad hoc technical expert group known as the Emergency Committee;

3. scientific principles, available scientific evidence, and other related information; and

4. an assessment of the risk to human health, of the risk of international spread, and of the risk of interference with international traffic. $^{6}$

This PHEIC declaration has since been employed by WHO six times to control the international spread of infectious disease: polio, Zika, Influ- 
enza H1N1, Ebola (in West Africa and then in the Congo), and most recently in the ongoing global struggle against COVID-19.

Beyond the international declaration of a PHEIC, the IHR bind states to build their domestic capacities to prevent, detect, and respond to infectious disease. Using the normative power of global health law to frame national efforts to contain disease, the IHR set concrete obligations for governments to strengthen national public health capacities and improve global health security. States retain sovereign authority to develop national health legislation, but this domestic legislation "should uphold the purpose" of the IHR, reinforcing international commitments. ${ }^{7}$ These international health commitments extend to human rights law, with the IHR requiring that domestic implementation "shall be with the full respect for the dignity, human rights and fundamental freedoms of persons." 8 Thus, national measures under the IHR must be based on scientific risk assessment and must not be more restrictive of international traffic, or more intrusive to individuals, than reasonably available alternatives. ${ }^{9}$ Where nations lack the capacity to meet these commitments, the IHR provide a path for international collaboration and assistance in the development, strengthening, and maintenance of national public health capacities. ${ }^{10}$

Under this international legal framework for global health security, WHO plays a coordinating role in supporting member states to strengthen health systems and build public health capacities. However, states were slow to reform their public health capacities following IHR (2005), pushing WHO to work with states in 2016 to develop monitoring mechanisms to facilitate accountability for public health law reforms. The resulting Joint External Evaluation (JEE) has provided a monitoring and evaluation tool to assess IHR implementation at the country-level, creating an independent expert review process to: assess national progress in meeting IHR core capacities, find gaps in implementation, and iden- tify best practices. ${ }^{11}$ This voluntary, collaborative, multisectoral process seeks to help countries strengthen their capacities to prevent, detect, and rapidly respond to public health threats. Yet despite these evolving efforts to support states in building public health capacities and meeting IHR responsibilities, many states continue to shoulder weak health systems with inadequate legal capacity. ${ }^{12}$

\section{Implementing the IHR in the COVID-19 Response}

The COVID-19 pandemic has brought into sharp focus the limitations of the IHR in (1) notifying WHO of public health risks; (2) declaring a PHEIC where necessary in the international response; (3) coordinating national responses commensurate with public health risks; and (4) fostering global solidarity for infectious disease prevention, detection, and response.

From the initial outbreak in China, notification delays significantly hampered WHO's ability to understand the scope of the threat and coordinate the international response. Although China first reported a case of novel coronavirus to WHO on December 31,2019 , retrospective analyses have demonstrated that SARS-CoV-2 was already circulating in Wuhan for several weeks prior to the first WHO notification. ${ }^{13}$ One of the principal IHR reforms in 2005 sought to allow WHO to take account of non-state ("unofficial") sources of information, recognizing that governments are often reluctant to notify WHO of novel pathogens within their borders; however, this innovation was ineffective in the early days of the COVID-19 outbreak, as Chinese authorities repressed health workers, scientists, and civil society in December 2019 - keeping them from sharing timely concerns about a novel coronavirus in Wuhan. ${ }^{14}$ (As the IHR does not provide WHO with the authority to investigate events independently, the IHR requirement for WHO to verify reports received from non-state sources with the relevant state dismantled an additional channel through which WHO could have received the necessary information. ${ }^{15}$ ) Legitimate questions remain as to what Chinese authorities knew, when they learned it, and whether they notified WHO in a "timely, accurate and sufficiently detailed" manner in accordance with the $\mathrm{IHR}^{16}$ - or whether, as with SARS, the response was impeded by the information politics of autocratic governance, leaving WHO with insufficient information to promptly declare a PHEIC.17

Even after China notified WHO about this coronavirus outbreak, the IHR failed to facilitate WHO's rapid declaration of a PHEIC, delaying global preparations for a pandemic response. With inadequate reporting and a split in expert opinion, WHO Director-General Tedros Adhanom Ghebreyesus convened an Emergency Committee on three occasions in late January 2020 to advise on the declaration of a PHEIC, as the Committee continued to find that it was "too early" and that there were "a limited number of cases abroad."18 (The definition of a PHEIC may have been misapplied at this critical juncture, as neither the timing of the threat nor the actual international spread of disease are constitutive elements of a PHEIC - on the latter question, there need only be the "potential" for international spread.19) A PHEIC was finally declared on January 30th, by which point the coronavirus was well on its way to becoming a pandemic - something WHO would not formally acknowledge until March 11th. ${ }^{20}$ Global health law scholars have long questioned WHO's tentative approach to declaring a PHEIC, arguing that where the IHR definition is met, a PHEIC declaration can spur action, investment, and solidarity from the international community. ${ }^{21}$ Yet, WHO has remained diplomatically hesitant to exercise its authority to declare a PHEIC, apprehensive of a declaration that could devastate the economies of affected states and spur nationalist measures that hamper global coordination. ${ }^{22}$

Following this PHEIC declaration, states have responded with overwhelming restrictions on international traffic, individual rights, and global commerce - with these nationalist restrictions taken in direct contravention of WHO recommenda- 
tions. In responding to PHEICs under the IHR, state responses are expected to adhere to WHO's temporary recommendations and other IHR parameters. ${ }^{23}$ Where states apply other health measures, such measures are required under the IHR to achieve equal or greater health protection than WHO recommendations and be: erected cordon sanitaires (guarded areas where individuals may not enter or leave). ${ }^{26}$ (WHO praised China's containment efforts as "ambitious, agile and aggressive," ${ }^{27}$ yet it has since tempered its enthusiasm for such restrictions on individual liberties. ${ }^{28}$ ) Even as evidence increasingly points to the need for widespread

\section{The future of global health must have international law at its foundation, and the WHO Director-General has already advocated for strengthening the IHR to reflect an independent assessment of the COVID-19 response. When the pandemic recedes, WHO must mobilize its member states to undertake this major review of international legal authorities, including WHO's institutional structure, to realize the promise of global health law in addressing future infectious disease threats.}

1. based on scientific principles, and available scientific evidence, or where such evidence is insufficient, on advice from the WHO and other relevant intergovernmental organizations;

2. not more invasive to persons or more restrictive of international traffic than reasonably available alternatives; and

3. implemented with full respect for the dignity, human rights and fundamental freedom of persons. ${ }^{24}$

Although states have disregarded WHO recommendations in the past by enacting travel and trade restrictions, the sheer scale of violative state actions - including travel bans, flight suspensions, visa restrictions, and border closures - has brought interactions within and between countries to a grinding halt. ${ }^{25}$ Governments rapidly instituted domestic Stayat-Home orders, closed businesses, banned public gatherings, and even confront the COVID-19 pandemic through global governance, states have reverted to isolationist policies, geopolitical competition, and global neglect. This shortsightedness amidst the COVID-19 pandemic, neglecting WHO guidance and threatening WHO support when global governance is needed most, has exposed the world to staggering humanitarian upheaval, economic instability, and health insecurity. ${ }^{33}$

The world is now paying in immeasurable human suffering for these compounding IHR violations, with COVID-19 presenting a lasting threat to health security, human rights, and the rule of law. ${ }^{34}$ Where states fail to uphold global health law, the world loses the ability to mitigate common threats through collective action. The future of global health must have international law at its foundation, and the WHO DirectorGeneral has already advocated for strengthening the IHR to reflect an independent assessment of the COVID-19 response. When the pandemic recedes, WHO must mobilize its member states to undertake this major review of international legal authorities, including WHO's institutional structure, to realize the promise of global health law in addressing future infectious disease threats.

\section{Revising Global Health Law to Meet Future Threats}

Global health law has proven unable to mitigate the threat of COVID-19, raising an imperative for international legal reforms to clarify state obligations, facilitate legal accountability, and realize global health security. Such holistic reforms of global health law will require either the undertaking of fundamental revisions to the IHR framework or the development of a new international legal instrument to structure global health governance.

Strengthening global governance, it will be necessary to ensure that WHO is amply funded and politically supported, empowering it to "speak truth to power" in confronting governments that do not comply with science-based recommendations. This will require critical reforms of 
global health law, including revisions to provide authority for:

\section{- Enhanced Surveillance and Man-} datory Reporting - allowing for unofficial data sources, including civil society and academic experts, and the independent collection of public health data where necessary by WHO staff; ${ }^{35}$

- Transparency in PHEIC Deliberations - allowing for open and independent EC decision-making ${ }^{36}$ and shifting from a binary trigger to a tiered system of multiple levels of public health emergency to spur commensurate state responses; ${ }^{37}$

- Rapid छ Public Monitoring of State Measures - allowing for scrutiny of state decisions that do not comply with WHO guidance, with monitoring and review in global economic governance, under international trade law, and through the human rights system; and

- Global Funding Mechanisms allowing for the development of new or reformed global governance institutions to pool international funding and bolster technical support for the development of sustainable national public health systems to prevent, detect, and respond to outbreaks. ${ }^{38}$

Developed through global health law reforms, WHO has authority under its constitution to negotiate conventions (art. 19), regulations (art. 21), and recommendations (art. 23), and all of these authorities should be considered in either:

- Revising the IHR architecture to reflect the imperative for reforms - with built-in and ongoing processes to amend the IHR in accordance with the changing nature of future public health emergencies and evolving scientific knowledge;

- Drafting a Framework Convention on Infectious Disease - with binding obligations and accountability mechanisms under a newly-nego- tiated legal instrument, supported by compliance mechanisms, periodic meetings of states parties, and dispute settlement processes; ${ }^{39}$ or

- Providing standing WHO recommendations on necessary state responses - with detailed WHO guidance on appropriate national policies and regular empirical analysis of the impact of public health laws on public health outcomes.

States will be the ultimate decisionmakers in these next steps, yet these reforms must recognize the ongoing struggle that states have faced in preventing, detecting, and responding to infectious disease. Where the COVID-19 pandemic has presented an unprecedented threat to global health, impacting every country throughout the world, it will be urgently necessary at the earliest appropriate moment to reshape the global health law landscape to respond collectively to the common threat of future pandemics.

Note

The authors have no conflicts to disclose.

\section{References}

1. L. O. Gostin and B. Mason Meier, "Introducing Global Health Law, Journal of Law, Medicine छ' Ethics 47, no. 4 (2019): 788-793. See also Lawrence O. Gostin, Global Health Law (Harvard University Press, 2014).

2. D. P. Fidler, "Germs, Governance, and Global Public Health in the Wake of SARS," Journal of Clinical Investigation 113, no. 6 (2004): 799-804.

3. L. O. Gostin and A. S. Ayala, "Global Health Security in an Era of Explosive Pandemic Potential," Journal of National Security Law Eீ Policy 9, no. 1 (2017): 53-80.

4. International Health Regulations (IHR) (Geneva: World Health Organization, 2005), art. 1 [hereinafter IHR].

5. IHR, Annex 2.

6. IHR, art. 12; D. P. Fidler and L. O. Gostin, "The New International Health Regulations: An Historic Development for International Law and Public Health," Journal of Law, Medicine है Ethics 34, no. 1 (2006): 85-94.

7. IHR, art. 4 .

8. IHR, art. 3(1). See also S. Negri, Communicable Disease Control, in Research Handbook on Global Health Law (2018): 265-302.
9. IHR, art. 43. See also B.M. Meier, D.P. Evans, and A. Phelan, "Rights-Based Approaches to Preventing, Detecting, and Responding to Infectious Disease," in Infectious Diseases in the Ner Millennium: Legal and Ethical Challenges (2020): 217-253.

10. IHR, art. 44; See also L. O. Gostin and R. Katz, "The International Health Regulations: The Governing Framework for Global Health Security," Milbank Quarterly 94, no. 2 (2016): 264-313.

11. World Health Organization, IHR (2005) Monitoring and Evaluation framework: Joint External Evaluation Tool (WHO 2018).

12. B. M. Meier, K. Tureski, E. Bockh, D. Carr, A. Ayala, A. Roberts, L. Cloud, N.Wilhelm, and S. Burris, "Examining National Public Health Law to Realize the Global Health Security Agenda," Medical Law Review 25, no. 2 (2017): 240-269.

13. C. Huang et al., "Clinical Features of Patients Infected with 2019 Novel Coronavirus in Wuhan, China," The Lancet 395, no. 10223 (2020): 497-506.

14. L. Yuan, "China Silences Critics Over Deadly Virus Outbreak," New York Times, January 25, 2020 , available at <https://www.nytimes. com/2020/01/22/health/virus-corona. html> (last visited April 4, 2020); L. Garrett, "Grim Reapers: How Trump and $\mathrm{Xi}$ set the Stage for the Coronavirus Pandemic," The Ner Republic, April 2, 2020, available at <https://newrepublic.com/article/157118/trump-xijinping-america-china-blame-coronavirus-pandemic > (last visited April 4, 2020); C. Buckley and S. L. Myers, "China's Old Habits Delayed Fight," New York Times, February 1, 2020 , available at <https://www.nytimes. com/2020/02/01/world/asia/chinacoronavirus.html> (last visited April 4, 2020); Chinese Human Rights Defenders, China: Protect Human Rights While Combatting Coronavirus Outbreak (2020), available at <https://www.nchrd.org/2020/01/ china-protect-human-rights-whilecombatting-coronavirus-outbreak/> (last visited April 5, 2020).

15. IHR, Art 9(1)

16. IHR, Art. 6(2); R. Ratcliffe and M. Standaert, "China Coronavirus: Mayor of Wuhan Admits Mistakes," The Guardian, January 27, 2020, available at <https://www.theguardian.com/science/2020/jan/27/china-coronaviruswho-to-hold-special-meeting-in-beijing-as-death-toll-jumps > (last visited April 4, 2020).

17. M. M. Kavanagh, "Authoritarianism, Outbreaks, and Information Politics," Lancet Public Health 5, no. 3 (2020): E135-E136.

18. International Health Regulations Emergency Committee on novel coro- 
navirus in China: January 23, 2020, (2020).

19. IHR, art. 12; M. Eccleston-Turner, "COVID-19 Symposium: The Declaration of a Public Health Emergency of International Concern in International Law," Opinion Juris (2020), available at <http://opiniojuris.org/2020/03/31/ covid-19-symposium-the-declarationof-a-public-health-emergency-ofinternational-concern-in-internationallaw/> (last visited April 4, 2020).

20. T. A. Ghebreyesus, "WHO DirectorGeneral's Opening Remarks at the Media Briefing on COVID-19 - 11 March 2020," World Health Organization (2020), available at <https:// www.who.int/dg/speeches/detail/whodirector-general-s-opening-remarksat-the-media-briefing-on-covid19---11-march-2020> (last visited April $6,2020)$.

21. Horton, "The Politics of PHEIC," Lancet 393 (2019): 2470; L. O. Gostin and R. Katz, "The International Health Regulations: The Governing Framework for Global Health Security," Milbank Quarterly 94 (2016): 264-313.

22. SC Res. 2177, paras. 3-4 (Sept. 18, 2014).

23. IHR, art 43(1)-(2).

24. IHR, art $43(3)$.

25. R. Habibi et al., "Do Not Violate the International Health Regulations During the COVID-19 Outbreak," Lancet 395, no. 10225 (2020): 664-666; B. Mason Meier, R. Habibi, and Y. T. Yang, "Travel Restrictions Violate International Law," Science 367 (2020): 1436-1436; Coronavirus disease 2019 (COVID-19): Situation Report - 67, WHO, available at <https://www.who. int/docs/default-source/coronaviruse/ situation-reports/20200327-sitrep67-covid-19.pdf?sfvrsn=b65f68eb_4> (last visited May 15, 2020).
26. "One Third of Humanity Under Virus Lockdown," Agence France Presse, March 25, 2020, available at <https:// www.afp.com/en/news/15/one-thirdhumanity-under-virus-lockdown-doc1q57be16> (last visited May 15, 2020).

27. Report of the WHO-China Joint Mission on Coronavirus Disease 2019 (COVID-19) (World Health Organization, Geneva, 2020).

28. T. A. Ghebreyesus, "WHO DirectorGeneral's opening remarks at the media briefing on COVID-19 - 11 March 2020," World Health Organization (2020), available at <https:// www.who.int/dg/speeches/detail/whodirector-general-s-opening-remarksat-the-media-briefing-on-covid19---11-march-2020> (last visited April 6, 2020).

29. S. Lai et al., Effect of Non-Pharmaceutical Interventions for Containing the COVID-19 Outbreak in China, medRxiv 2020.03.03.20029843 (2020).

30. D. P ras et al., "The Right to Health Must Guide Responses to COVID-19," Lancet (forthcoming).

31. IHR, art. 44.

32. P. Farmer and J. Mukherjee, "Ebola's Front Lines," Boston Globe, September 24, 2014, available at <https://www. bostonglobe.com/opinion/2014/09/23/ responding-ebola-countries-needstaff-stuff-space-and-systems/ugSFKkOw9S7Ser0p8PGeOK/story.html> (last visited April 6, 2020).

33. A. Guterres, "Secretary-General's Opening Remarks at Virtual Press Encounter on COVID-19 Crisis," United Nations Secretary-General (2020), available at <https://www.un.org/sg/en/content/sg/ speeches/2020-03-19/remarks-virtualpress-encounter-covid-19-crisis> (last visited Apr 6, 2020)

34. The UN Security Council declared for the first time that a public health issue was a threat to international peace and security in Resolution 2177, referring to the Ebola outbreak in West Africa. It is expected to issue a similar resolution on the COVID-19 pandemic in early April 2020.

35. L. O. Gostin and R. Katz, "The International Health Regulations: The Governing Framework for Global Health Security," in Global Management of Infectious Disease After Ebola (2016): 101-132.

36. M. Eccleston-Turner and A. KamradtScott, "Transparency in IHR Emergency Committee Decision Making: The Case for Reform," BMJ Global Health 4 (2019): e001618.

37. M. S. Green, "Did the Hesitancy in Declaring COVID-19 a Pandemic Reflect a Need to Redefine the Term?" Lancet (2020): 1034-1035.

38. WHO, Implementation of the International Health Regulations (2005): Report of the Review Committee on Second Extensions for Establishing National Public Health Capacities and on IHR Implementation: Report by the director-general, para. 17 (Mar. 27, 2015), available at <http://apps. who.int/gb/ebwha/pdf_files/WHA68/ A68_22Add1-en.pdf $>$ (last visited May 15, 2020); S. Moon et al., "Will Ebola Change the Game? Ten Essential Reforms Before the Next Pandemic. The Report of the Harvard-LSHTM Independent Panel on the Global Response to Ebola," The Lancet 386 (2015): 2204-2221.

39. D. P. Fidler, International Law and Infectious Disease (1999). 